\title{
Orman Fonksiyon Önceliklerinin Belirlenmesi: Çelikhan Plan Ünitesi Örneği
}

\author{
Nuri BOZAL $\dot{I}^{1 *}$ \\ ${ }^{1}$ Karadeniz Teknik Üniversitesi, Orman Fakültesi, Orman Mühendisliği Bölümü, 61100, Trabzon
}

\section{Öz}

Bütün dünyada olduğu gibi ülkemizde de hızlı nüfus artışı doğal kaynaklardan beklentiyi artırmakta ve çeşitlendirmektedir. İnsanların ormanlardan beklentilerinin çeşitlenmesi ve artması ormanların topluma sunmuş olduğu ekolojik ve sosyo-kültürel fonksiyonları ön plana çıarmaktadır. Orman amenajman planlarının yapılmasında çok önemli bir altlık olarak değerlendirilen ve ormanların topluma sağladığı faydaları gösteren orman fonksiyon haritalarının oluşturulması son derece önem arz etmektedir. Bu amaçla Çelikhan plan ünitesi örneğinde toprak koruma, su üretimi, estetik ve rekreasyon fonksiyonlarına ayrılacak alanlar ölçüt ve göstergelere göre belirlenerek her bir fonksiyon için ayrı ayrı haritalar oluşturulmuştur. Bu çalışmada toprak koruma fonksiyonunu belirlemek için kullanılan eğim parametresine ilaveten anakaya grupları ile meşcere yapısı, kök sistemi ve kapalılık biçimi gibi yeni parametreler bir arada kullanılarak toprak koruma fonksiyonu erozyon risk grupları oluşturulmuştur. Tüm fonksiyonlar farklı renkler kullanılarak veya taranarak tek bir harita üzerinde birleştirilmiş ve bütün fonksiyonlar meşcere tipleri haritası ile çakıştırılarak plan ünitesinde tek ve çok fonksiyonlu alanlar belirlenmiştir. Bu amaçla plan ünitesindeki her bölme ve bölmeciğin göreceği fonksiyon ya da fonksiyon grupları belirlenerek haritalandırılması yapılmıştır. Plan ünitesi içerisindeki konumsal orman fonksiyonları ile bireysel ve kurumsal talebe konu olan estetik ve rekreasyon fonksiyonları ayrıldıktan sonra erozyon riskinin az ve eğimin düşük olduğu alanlar üretim fonksiyonuna ayrılmıștır. Orman fonksiyon haritasına göre; I. fonksiyonların dağglımına göre toprak koruma, su üretimi, odun üretimi, rekreasyon, estetik ve ormansız alanlar sirasıyla \%9,61, $\% 9,27, \% 0,31, \% 0,04, \% 0,46$ ve $\% 61,54$ ' ünü oluşturmaktadır. Orman fonksiyonların belirlenmesinde katılımc1 yaklaşım kullanılarak orman kaynaklarının planlanması ve yönetilmesi ile sürdürülebilir ormancılık işletmeciliğine katkı sağlanacaktır.

Anahtar Kelimeler: Toprak koruma, Su üretimi, Estetik, Rekreasyon, Orman fonksiyonu.

\section{Determination of Forest Function Priorities: A Case of Çelikhan Planning Unit}

\begin{abstract}
The rapid population growth in our country, as in the whole world, increases and diversifies expectations from natural resources. The diversification and increase of people's expectations from forests bring the ecological and socio-cultural functions that forests offer to the society. It is extremely important to produce forest value maps that are considered as a very important base in the preparation of forest management plans and show the benefits of forests to society. For this purpose, the areas to be allocated to soil conservation, water production, aesthetics and recreation functions in the example of Çelikhan plan unit were determined according to criteria and indicators, and separate maps were created for each function. In this study, in addition to the slope parameter used to determine the soil conservation function, soil conservation function erosion risk groups were formed by using bedrock groups and new parameters such as stand structure, root system and canopy shape. All functions were combined on a single map by using different colors or by scanning, and single and multi-functional areas were determined in the plan unit by overlapping all functions with the stand types map. For this purpose, the function or function groups that will be seen by each compartment and division in the plan unit were determined and mapped. The spatial forest functions in the plan unit and the aesthetic and recreational functions subject to individual and institutional demands were separated, and then the areas with low erosion risk and low slope were allocated to production functions. According to the forest function map; according to the distribution of I. functions, soil conservation, water production, wood production, recreation, aesthetics and deforested areas constitute $9.61 \%, 9.27 \%, 0.31 \%, 0.04 \%$, $0.46 \%$ and $61.54 \%$, respectively. Contribution will be made to sustainable forestry management by using a participatory approach in determining forest functions, planning and managing forest resources.
\end{abstract}

Keywords: Soil protection, Water production, Aesthetic value, Recreation, Forest function. 


\section{Giriş}

Orman ekosistemlerinde kendiliğinden oluşan mal ve hizmetler orman fonksiyonu olarak adlandırılmaktadır. Bu fonksiyonlar toplumun sosyal, kültürel ve ekonomik özelliklerinin yanında yörenin ekolojik özelliklerine göre de değişiklik göstermektedir (Şafak, 2009). 1993 yılında düzenlenen Helsinki Konferansı'nda orman fonksiyonları ekonomik, ekolojik ve sosyo-kültürel olmak üzere üç gruba ayrılırken aynı zamanda, uluslar arası tanımının yapılarak genel esaslarının belirlendiği sürdürülebilir orman işletmeciliği kavramı literatürdeki yerini almıştır. Ülkemizde bu doğrultuda Asan vd. (2005) tarafından yapılan gruplandırmada, içerikleri her ülkenin durumuna göre değişen, kolayca paraya çevrilebilen ve gelir getiren odun ve odun dişı orman ürünleri ile, rekreasyon, av ve yaban hayatı gibi mal ve hizmetlerin üretildiği ormanlar ekonomik fonksiyonlu ormanlar; doğrudan paraya çevrilemeyen fakat yaşanabilir çevre için hayati öneme sahip olan toprak, su, iklim ve doğanın koruma ve geliştirilmesine ilişkin fayda ve fonksiyonlar ekolojik; toplum sağlığı, estetik ve bilimsel araştırma gibi fayda ve fonksiyonlar ise sosyo-kültürel fonksiyon grubu içinde sınıflandırmaktadır. $\mathrm{Bu}$ fonksiyonların hangisi veya hangilerinin önemli olacağı zamanla ve bölgesel farklılıklarla ortaya çıkabilmektedir. Ormanların topluma sunmuş olduğu fayda ve fonksiyonlara toplum tarafindan talep olması durumunda bu fonksiyonlar amaca dönüşmektedir. Bundan dolayı plan ünitelerinde birden çok fonksiyon çakışabilmektedir (Mısır, 2005).

Ülkemizde orman amenajman planları yapılırken, yalnızca yuvarlak odun üretimi olan ormanlarda ağaç türü ve idare süresine göre işletme sınıfı ayırımı gerçekleştirilmekteydi. 2008 yılından itibaren Ekosistem Tabanlı Fonksiyonel Planlama (ETFOP) yaklaşımına geçilmesiyle birlikte; işletme sınıfı ayırımı orman fonksiyonlarına dayandırılmaktadır. Asan (1999) fonksiyonel yaklaşımla işletme sınıfına ayırma sürecini dört ana başlık altında toplamıştır. Bunlar;

$\checkmark \quad$ Plan ünitesinde öne çıkan konumsal orman fonksiyonlarının her birisini diğerlerinden bağımsız olarak ele alarak sınırlarının harita üzerine geçirilmesi,

$\checkmark$ Değişik fonksiyon haritalarının çakıştırılmasıyla nihai fonksiyon haritasının düzenlenmesi,

$\checkmark$ Fonksiyon haritası üzerinde tek ve çok fonksiyonlu alanların ayrılması,

$\checkmark$ Aynı tek fonksiyon ya da fonksiyon grubu içine giren alanların ayrı bir renk ile sınırlandırılması ve adlandırılmasidir.

Ormancılığı gelişmiş olan Amerika ve Kanada gibi ülkeler kamuya ait ormanların planlanmasında çok amaçlı planlamayı kullanmaktadırlar (Zengin vd., 2013; Bettinger et al., 2013). Ülkemizde odun üretiminin yanında diğer ürün ve hizmet değerlerini dikkate alan planlama çalışmaları yapılmıştır (Köse, 1986; Köse vd., 1998; Yolasığmaz, 1998; Mısır, 2001; Mısır ve Başkent, 2002; Keleş, 2003; Karahalil, 2003; Keleş vd., 2005; Zengin, 2009; Baskent ve Kucuker, 2010; Kucuker ve Başkent, 2017).

Orman fonksiyonlarının belirlenmesi amacıyla, İstanbul Orman Bölge Müdürlüğüne bağl1, Bahçeköy Orman İşletme Müdürlüğü, Adalar, Gaziosmanpaşa, Kemerburgaz ve İstanbul şefliklerinde (Asan, 1990; Asan, 1992; Asan ve Yeşil, 1993), İ.Ü. Orman Fakültesi Eğitim ve Araştırma Ormanında (Asan, 1995; Asan vd., 1997; Asan, 1999), İzmit-Kerpe Araştırma Ormanında (Asan ve Ercan, 2002), İstanbul Anakent Belediyesine ait korularda (Asan ve Özdemir, 2002) ve Düzce Odayeri orman işletme şefliğinde (Bozali, 2013) fonksiyonel haritalama çalışmaları birden fazla fonksiyona sahip alanlarda fonksiyon kombinasyonları oluşturularak fonksiyon öncelikleri uzman görüşüne dayanarak gerçekleştirilmiştir. Ayrıca İzmir'de (Geray vd., 2007), Ulus Orman İşletme Müdürlüğünde (Daşdemir ve Güngör, 2010) ve Mersin ilinde (Yılmaz vd., 2010) çok kriterli ve katılımcı yaklaşımla karar vermeye yarayan Analitik Hiyerarşi Süreci (AHS) tekniğini kullanarak fonksiyon önceliklerini belirlemişlerdir.

Yapılan bu çalışma ile toprak koruma fonksiyonuna ayrılacak alanların belirlenmesinde farklı bir yöntem kullanılarak fiili erozyonun yanında gizli risk taşıyan alanlarda belirlenecektir. Toprak koruma, su üretimi, estetik ve rekreasyon fonksiyonlarına ayrılacak alanlar ölçüt ve göstergelere göre belirlenerek her bir fonksiyon için ayrı ayrı haritalar oluşturulacaktır. Tüm fonksiyonlar farklı renkler kullanılarak veya taranarak tek bir harita üzerinde birleştirilerek bütün fonksiyonlar meşcere tipleri haritası ile çakıştırılarak plan ünitesinde tek ve çok fonksiyonlu alanlar tespit edilecektir. Uygulanacak silvikültürel işlemler ana fonksiyona göre değişeceği için birden fazla fonksiyona sahip olan alanlarda hangi fonksiyonun birincil, hangisinin ikincil olduğunun belirlenmesi gerekmektedir. Bunu gerçekleştirmek için katılımcı yaklaşımdan faydalanılmıştır. Plan ünitesindeki her bölme ve bölmeciğin göreceği fonksiyon ya da fonksiyon grupları belirlenerek haritalandırılması yapılacaktır. Bu amaçla uygulayıcılara orman fonksiyonların tespit edilmesinde bir bakış açısı vererek altlık oluşturulması düşünülmektedir. 


\section{Materyal ve Metot}

\subsection{Materyal}

$\mathrm{Bu}$ çalışmada; alanının konumsal orman fonksiyonlarının belirlenmesi için Şanlıurfa Orman Bölge Müdürlüğünden temin edilen sayısal meşcere tipleri haritası ile 1/25.000 ölçekli sayısal topoğrafik haritalar kullanılarak alanın Sayısal Arazi Modeli (SAM) oluşturulmuştur. Alanın jeolojik yapısı Maden Teknik Arama (MTA) Genel Müdürlüğü'nün 1/100.000 ölçekli jeoloji haritasından yararlanılarak sayısallaştırılmış ve anakaya grupları oluşturulmuştur (Anonim, 1986).

Çalışma alanı Şanlıurfa Orman Bölge Müdürlüğü, Adıyaman Orman İşletme Müdürlüğü’ne bağlı Çelikhan orman işletme şefliğidir (Şekil 1). Şeflik 13,291.2 ha’1 ormanlık alan ve 52,865.8 ha'1 açıklık alan olmak üzere toplam 66,157.0 ha'lık bir alana sahiptir. Alandaki hakim ağaç türleri Pinus nigra Arn., Cedrus libani A.Rich., Juniperus sp., Quercus sp., Almond, Robinia pseudoacacia' dır. Şeflik içerisindeki ormanlar yazları çok sıcak ve kurak, kışları kar bakımından zengin ve daha soğuk, yağışlı bir ilkbahar karakteristiği taşıyan karasal iklim bölgesinde kalmaktadır. Alanın yükseltisi 630 m'den başlayıp 2605 m’ye kadar çıkmaktadır. Eğim çoğunlukla \%31-60 arasında kalmakta olup orta derecede erozyona hassas alanlar içerisinde kalmaktadır.

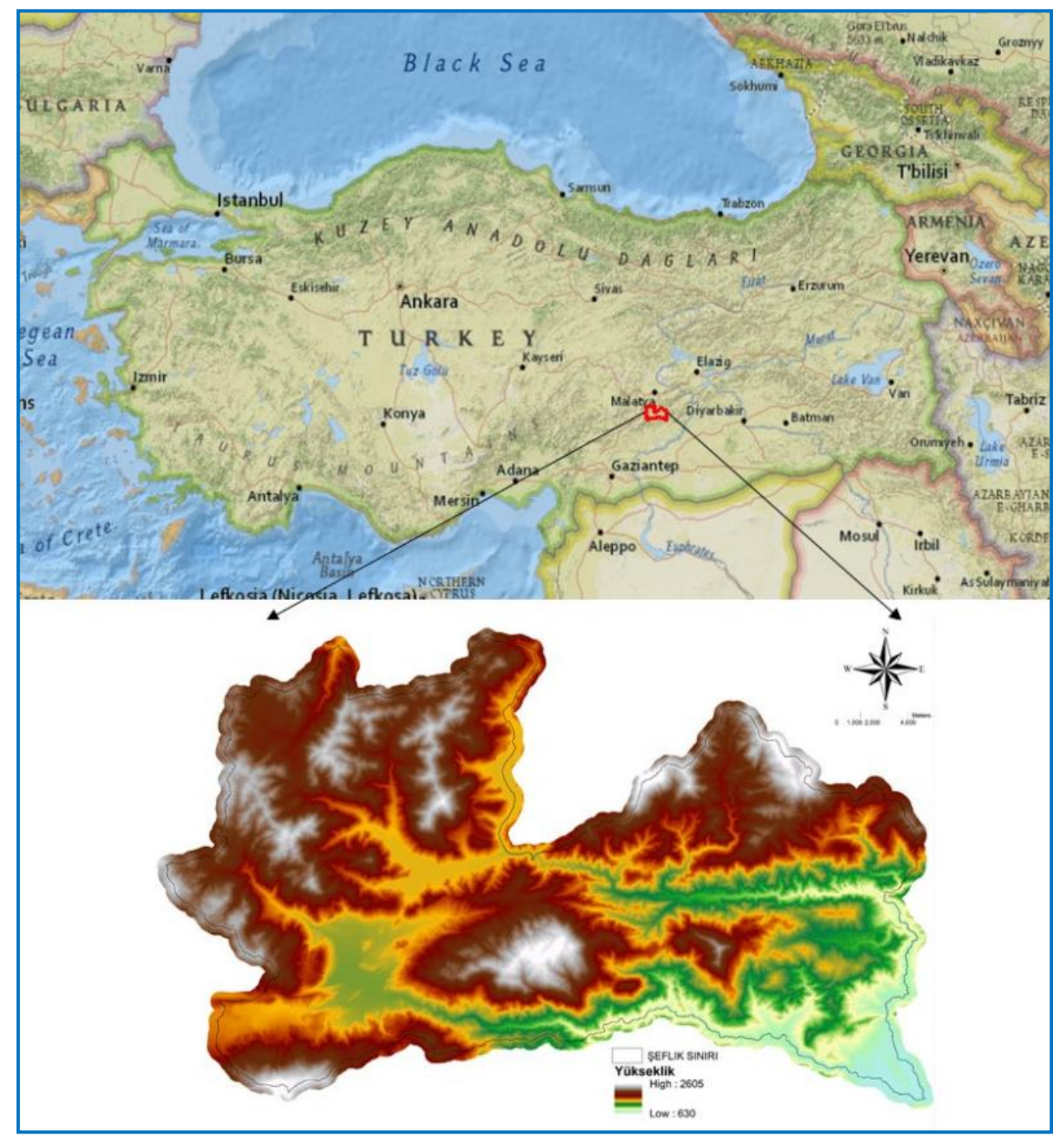

Şekil 1. Çalışma alanının genel konumu.

\subsection{Metot}

Orman fonksiyonları belirlenirken ekolojik ve sosyal fonksiyonlu alanların ayrılmasına öncelik verilerek, kalan 
kısımların ağırlıklı olarak orman ürünleri üretimine ayrılması gerektiği düşüncesinden hareket edilmişstir. Çalışma alanı sınırları içerisinde yasalar ya da mevzuatlar gereği mutlak anlamda korumaya ayrılması zorunlu alanlar bulunmamaktadır. Konumsal fonksiyonlar belirlenirken kullanılacak verilerden bir kısmı sayısal arazi modeli üzerine bölmecik haritası eklenerek çalışma alanının kabartma haritası elde edilerek yapılmıştır.

Fonksiyon haritaları düzenlenirken önce her bir fonksiyon diğerlerinden bağımsız olarak düşünülmek suretiyle, mevcut ölçüt ve göstergelere göre belirlenen fonksiyonlar harita üzerinde işaretlenir. Daha sonra tüm fonksiyon haritaları çakıştırılmak suretiyle de nihai fonksiyon haritası elde edilir (Asan, 1999; Bozali, 2013). Bu haritada bir alan birden fazla fonksiyona ayrılmış olabilir. Plan ünitesi içinde öne çıkan fonksiyonlar aşağıda açıklandıkları şekilde belirlenmiştir.

\subsection{Toprak Koruma Fonksiyonuna Ayrılacak Alanların Belirlenmesi}

Toprak koruma fonksiyonuna ayrılacak alanlar belirlenirken, arazi üzerinde görünen fiili erozyonun yanında gizli risk taşıyan alanların da tespit edilmesi hedeflenmiştir (Asan ve Özdemir, 2002). Bu amaçla toprak koruma fonksiyonuna ayrılacak alanlar aşağıdaki ölçütler dikkate alınarak üç farklı risk grubuna göre derecelendirilmiştir:

$\checkmark$ Eğim

$\checkmark$ Anakaya

$\checkmark \quad$ Kök Sistemi (sı̆̆ , yürek, kazık)

$\checkmark \quad$ Kapalılık (Boşluklu kapalı, seyrek ya da gevşek kapalı, orta kapalı ve normal kapalı)

$\checkmark$ Açık alanlar (Me, Z, OT, Ag0 vb.) gibi kriterler dikkate alınmış ve aşağıdaki şekilde bir değerlendirme yapılmıştır.

Plan ünitesinde toprak koruma fonksiyonunun öne çıktığı alanlar, arazi eğiminin \%30'u geçtiği alanlar olarak değerlendirilmiş ve eğim grupları Tablo 1'deki gibi oluşturulmuştur

Tablo 1. Erozyon riskinin eğim grubuna göre değişimi.

\begin{tabular}{lll}
\hline Eğim Grupları (\%) & Risk Grubu & Açıklama \\
\hline $0-30$ & III & Erozyona az duyarlı \\
$31-60$ & II & Erozyona orta derecede duyarlı \\
$61+$ & I & Erozyona çok duyarlı \\
\hline
\end{tabular}

Toprakların erodibilitesi erozyona duyarlılı̆̆ı etkileyen etmenlerin başında gelmektedir. Erodibilitesi düşük olan topraklar erozyona daha hassas olmaktadır. Toprakları, oluştukları ana materyalleri dikkate alarak erozyon eğilimleri bakımından ayırmak mümkündür. İç Anadolu'da incelenen dört ana materyal erodibilite derecelerine (erozyona olan duyarlılık) göre; Neojeon tozu > Kum taşı > Andezit > Konglemera şeklinde sıralanmıştır (Özhan, 2004). Çalışma alanı içerisindeki anakayalardan birisi olan kumtaşı ana kayasının erozyona çok duyarlı olduğu görülmektedir (Tablo 2).

Kayaların fiziksel ayrışması üzerinde yapılan deneysel araştırmalara göre fiziksel ayrışmaya en dirençli anakaya kireçtaşı iken en az dayanıklı olanı ise kumtaşıdır (Jenny, 1941'e atfen Balc1, 1996). Toprakları oluşturdukları ana materyalleri de dikkate alarak, erozyon eğilimleri bakımından ayırmak mümkün olmaktadır. Wallis ve Willen'e göre;

a) Granit, diorit, granadiorit ve bazı sediment ve şistleri erozyona karşı çok hassas

b) Bazı metamorfik kayalar erozyona orta derecede hassas

c) Bazı deniz sedimentleri, bazalt, gabro ve andezit erozyona dayanıklı (Dyrness'a atfen Balcı ve Öztan, 1987).

$\mathrm{Bu}$ doğrultuda araştırma alanı için anakaya gruplarının erozyona karşı duyarlılıkları ve risk grupları Tablo 2'de verilmiştir.

Tablo 2. Anakaya yapısına göre erozyon risk grupları.

\begin{tabular}{lll}
\hline Anakaya & Risk Grubu & Açılama \\
\hline Kumtaşı, Şist, Sediment & I & Erozyona çok duyarlı \\
Karbonat, Ofiyolit, Yamaç molozu & II & Erozyona orta derecede duyarlı \\
Gabro, Kireçtaşı, Mermer & III & Erozyona az duyarlı \\
\hline
\end{tabular}


Ormanın kapalılığı ile erozyon arasında kuvvetli bir ilişkinin olduğu bilinmektedir. Kapalılığın kırılması erozyon oluşumunu tetiklemektedir. Ormanlar, vejetasyon ve ölü örtü sayesinde erozyonun olumsuz etkilerini en aza indirgemektedir. Vejetasyon kökleri ile toprakta iyi bir strüktür oluşturarak, permeabiliteyi ve infiltrasyonu artırarak yüzeysel akış ve erozyonu azaltıcı bir etki yapmaktadır (Balcı, 1978). Derin ağaç kökleri yamaçları sağlamlaştırır ve yüzeysel toprak kaymalarının önlenmesine yardım eder. Bu süreçte ağaçların kök sıklığı, kök yapısı, kök derinliği ve kök direnci eğim ve toprak stabilitesinin sağlanması açısından oldukça önemli bir parametredir (Ji et al., 2012). Bu doğrultuda plan ünitesi için meşcere yapısı ve kök sistemi dikkate alınarak erozyona olan duyarlılıkları belirlenmiştir (Tablo 3).

Tablo 3. Meşcere yapısı (kapalılık ve kök sistemi) göre erozyon risk grupları.

\begin{tabular}{llll}
\hline \multirow{2}{*}{ Meşcere Kapalılık } & Kök Sistemi & & \\
\cline { 2 - 4 } & Kazık & Yürek & Saçak \\
\hline Açık Alanlar (OT, Z, Me vb.) & - & - & - \\
Boşluklu Kapalı & II & II & I \\
Seyrek ya da Gevşek Kapalı & II & II & II \\
Orta Kapalı & III & III & II \\
Normal Kapalı & III & III & II \\
\hline
\end{tabular}

(I: Erozyona çok duyarlı, II: Erozyona orta derecede duyarlı, III: Erozyona az duyarlı).

Plan ünitesi için erozyon riski taşıyan alanların; eğim (ES), anakaya yapısı (AK), meşcere yapısı (kapalılık ve kök sistemi) (MY) göre ayrı ayrı haritaları oluşturulmuş ve bunlar üst üste çakıştırılarak I., II. ve III. derecede erozyona duyarlı alanlar belirlenerek nihai toprak koruma fonksiyon haritası oluşturulmuştur. Toprak koruma fonksiyonu (TKF) kapsamında üç derecede erozyona duyarlı alanlar belirlenirken;

$\mathrm{TKF}=3 \mathrm{ES}+2 \mathrm{AK}+1 \mathrm{MY}$

denklemi kullanılmıştır (Bozali, 2013). Erozyonun şiddeti bakımından eğim derecesi çok daha önemlidir. Eğimin $\% 5$ 'ten \%10'a çıkması halinde erozyon miktarında 3 katı bir artış, \%15'e çıkması halinde 5 katı bir artış olmaktadır (Anonim, 2002). Toprak koruma fonksiyonuna ayrılacak alanlarda eğimin öneminin diğerlerinden daha fazla olduğu ve bu yüzden en fazla ağırlık oranına sahip olacağı öngörüldüğünden; eğim (3) >anakaya yapısı (2) >meşcere yapısı (kapalılık ve kök sistemi) (1) şeklinde bir sıralama yapılmıştır (Bozali, 2020). Denklemde 1, 2 ve 3 rakamları ağırlık oranlarını göstermektedir. Oluşturulan denklemin minimum ve maksimum sınırları belirlendikten sonra 3 grup oluşturularak TKF için ayrılacak alanlar tespit edilmiştir. Denklemdeki minimum değer için 33 ve maksimum değer için 100 kullanılmıştır.

$\mathrm{TKF}=3 \mathrm{ES}+2 \mathrm{AK}+1 \mathrm{MY}=3 \times 100+2 \times 100+1 \times 1000=600$ üst sınır değeri

$\mathrm{TKF}=3 \mathrm{ES}+2 \mathrm{AK}+1 \mathrm{MY}=3 \times 33+2 \times 33+1 \times 33=198$ alt sınır değeri

Üst sınır değeri ile alt sınır değeri arasındaki fark 3 gruba ayrılarak TKF için sınır aralık değerleri belirlenmiştir (Tablo 4).

Tablo 4. Toprak koruma fonksiyonu risk gruplarının sınır aralıkları.

\begin{tabular}{lll}
\hline TKF Sınır Aralık Değerleri & Risk Grubu & Açıklama \\
\hline $198-332$ & III & Erozyona az duyarlı \\
$333-466$ & II & Erozyona orta derecede duyarlı \\
$467-600$ & I & Erozyona çok duyarlı \\
\hline
\end{tabular}

\subsection{Su Üretimi Fonksiyonuna Ayrılacak Alanların Belirlenmesi}

Plan ünitesi içerisinde hidrolojik fonksiyona ayrılacak alanların belirlenmesi amacıyla; mevcut baraj ve göletlerin su toplama havzaları ile içme suyu kaynaklarının etrafı doğal hatlar dikkate alınarak ayrılmaktadır (Asan, 1999; Özdemir vd., 2005). Herhangi bir yasal koruma statüsü olmayan alanlarda, su üretim fonksiyonunu görecek alanları tespit etmek, sınırlandırmak ve haritalandırmak için hem arazide gözlem yapmak hem de topografik haritalardan yaralanmak gerekmektedir (Kahveci, 1999). Mevcut çalışmada sayısal arazi modelinden (SAM) faydalanarak havzalarının su ayrım çizgileri esas alınarak su üretim fonksiyonuna ayrılacak alanların sınırları belirlenmiştir. Su üretim fonksiyonuna ayrılacak alanlar belirlenirken plan ünitesi içerisinde yer alan Çat baraj gölüne su sağlayan akarsular, sırt ve tepeler gibi doğal hatlar takip edilerek birinci derecede su üretim 
fonksiyonuna ayrılırken, plan ünitesinin kalan kısmı ise yazları sıcak ve kurak bir mevsim yaşandığı için ikinci derecede su üretim fonksiyonuna ayrılmıştır. Bu fonksiyona ayrılacak alanların sınırları geçirilirken bölmecik sınırlarına dayanmasına ve onları bölmemesine dikkat edilmiştir.

\subsection{Estetik Fonksiyona Ayrılacak Alanların Belirlenmesi}

Estetik fonksiyon, ormanların çevresini süsleme, güzelleştirme, doğal peyzajını tamamlama ve bunun estetik etkisini arttırma fonksiyonudur. Her işletme ve üretim ormanı formunun bu fonksiyonu az çok yerine getirmesi gerekir. İstenmeyen görüntülerin orman şeritleri ile perdelenerek gizlenmesi yoluyla ortaya çıkan orman fonksiyonu da estetik fonksiyon olarak kabul edilmektedir. Bu fonksiyonun hemen hemen tüm fonksiyonlarla ve özellikle hidrolojik, klimatik, doğayı koruma, toplum sağlığı, rekreasyon ve bilimsel fonksiyonlarla sıkı ilişkisi, etkisi ve ortak yönleri bulunmaktadır (Eraslan, 1982; Asan, 1990; Eler, 2001). Ana karayolları üzerinde, göze hoş gelmeyecek biçimde tıraşlama kesimlerinden uzak durularak, yol kenarlarında şeritler halinde ormanlar bırakılarak, yoldan geçenlerin kendilerini orman içinde seyahat ettiklerini düşünmeleri ancak her amenajman planında bu fonksiyon mutlaka göz önünde tutulursa sağlanabilir. Estetik değeri yüksek objelerin korunmasına özen gösterilmeli ve ekonomik düşüncelerle görsel kalite yok edilmemelidir. Estetik fonksiyon gören orman; doğanın ve çevrenin görüntüsünü bozan, görüntüsü ile insanları rahatsız eden taş, maden, mermer ocakları ile tuğla kiremit fabrikaları gibi tesisleri gizleyerek göze hoş gelen görüntüleri oluşturan alanlardır. Çelikhan ilçe merkezi ve karayolu etrafındaki genellikle dikimle oluşturulan saf karaçam meşcereleri estetik fonksiyon görecek alanlar olarak ayrılmış ve veri tabanında "1"ile kodlanmıştır. Estetik fonksiyona uygun olmayan alanlar ise "0" ile kodlanmıştır.

\subsection{Rekreasyon Fonksiyona Ayrılacak Alanların Belirlenmesi}

Rekreasyon anlamı, içeriği ve kapsamı bakımından birçok aktiviteyi içerisinde barındırmaktadır. Genel olarak boş zaman gibi herhangi bir zorunluluğun olmadığı zamanlarda eğlenme ve dinlenme amacıyla isteyerek yapılan hareket ya da hareketsizlik olarak tanımlanabilen rekreasyon kavramının değişen sosyo-kültürel ve ekonomik yapıya göre çok çeşitli tanımları yapılmaktadır (Butler et al., 1998). Baud-Bovy ve Lawson (1998)'a göre rekreasyon fazla mesai, ikinci iş, ev işleri gibi kişinin fazladan yüklendiği işlerin dışındaki boş zamanları dolduran aktivitelerdir.

İnsanların mutluluğuna, ruh ve beden sağlığına, ruhen yenilenmelerine ve huzur bulmalarına olanak sağlayan ormanlar rekreasyon fonksiyonu gören alanlar olarak ayrılmaktadır. Son yıllarda aşırı kentleşmenin baskısıyla toplum tarafından büyük talep görmektedir. Ormanların bu fonksiyonu sayesinde insanlar fiziksel ve psikolojik olarak dinlenirken doğayı yakından tanıma fırsatı da bulurlar. Plan ünitesi içerisinde yöre halkı tarafından rekreasyon amacıyla fiili olarak kullanılan alanlar rekreasyon fonksiyonu içerisinde değerlendirilmiş ve "1" ile kodlanmıştır. Rekreasyon fonksiyonuna uygun olmayan alanlar ise " 0 ”ile kodlanmıştır.

\section{7. Üretim Fonksiyona Ayrılacak Alanların Belirlenmesi}

Toprak koruma, su üretimi, estetik ve rekreasyon fonksiyonları görecek alanlar ayrı ayrı belirlenip ArcGIS ortamında meşcere haritası ile üst üste çakıştırıldıktan sonra, aynı bölmecikte toprak koruma fonksiyonunun 3. derece ve su üretim fonksiyonunun 2. derece (Tablo 5) öneme sahip oldukları alanlarda erozyon riskinin daha az olmasından dolayı bu alanlarda iç piyasanın yuvarlak odun üretimine olan talebin karşılanması için odun üretim fonksiyonuna ayrılmıştır.

\subsection{Fonksiyon Haritasının Düzenlenmesi}

Toprak koruma fonksiyonu, su üretimi, estetik ve rekreasyon fonksiyonuna ayrılacak alanlar yukarıda bahsedilen ölçüt ve göstergelere göre belirlenerek her bir fonksiyon için haritalar ArcGIS ortamında ayrı ayrı oluşturulmuştur. Tüm fonksiyonlar farklı renkler kullanılarak veya taranarak tek bir harita üzerinde çakıştırılmıştır. Tek bir harita üzerinde birleştirilen bütün fonksiyonlar meşcere tipleri haritası ile çakıştırılarak plan ünitesinde tek ve çok fonksiyonlu alanlar tespit edilmiştir. Bu amaçla plan ünitesindeki her bölme ve bölmecik tek tek ele alınarak her birisinin göreceği fonksiyon ya da fonksiyon grupları belirlenmiştir. Uygulanacak silvikültürel işlemler ana fonksiyona göre değişeceği için birden fazla fonksiyona sahip olan alanlarda hangi fonksiyonun birincil, hangilerinin ikincil olduğunun bilinmesi gerekmektedir. Ana ve yan fonksiyonlara karar verilirken ortaya çıkan kombinasyon çeşitliliği ve karar verilen fonksiyonlar Tablo 5'te gösterilmiştir. 
Tablo 5. Fonksiyon kombinasyonlarına göre karar verilen fonksiyonlar.

\begin{tabular}{lllll}
\hline \multicolumn{2}{l}{ Fonksiyon } & \multicolumn{3}{c}{ Fonksiyonların Öncelik Sıralaması } \\
\cline { 1 - 3 } TK & SK & E & R & \\
\cline { 1 - 3 } 0 & 1 & 0 & 0 & Su Üretimi (1. Derece) \\
0 & 2 & 0 & 0 & Su Üretimi (2. Derece) \\
1 & 2 & 0 & 0 & Toprak Koruma (1. Derece) + Su Üretimi (2. Derece) \\
2 & 1 & 0 & 0 & Toprak Koruma (2. Derece) + Su Üretimi (1. Derece) \\
2 & 1 & 1 & 0 & Toprak Koruma (2. Derece) + Su Üretimi (1. Derece) + Estetik \\
2 & 2 & 0 & 0 & Toprak Koruma (2. Derece) +Su Üretimi (2. Derece) \\
2 & 2 & 1 & 0 & Toprak Koruma (2. Derece) +Su Üretimi (2. Derece) + Estetik \\
2 & 2 & 0 & 0 & Toprak Koruma (2. Derece) +Su Üretimi (2. Derece) \\
3 & 1 & 0 & 0 & Toprak Koruma (3. Derece) + Su Üretimi (1. Derece) \\
3 & 1 & 1 & 0 & Toprak Koruma (3. Derece) + Su Üretimi (1. Derece) + Estetik \\
3 & 2 & 0 & 0 & [Toprak Koruma (3. Derece) + Su Üretimi (2. Derece)] Üretim \\
3 & 2 & 0 & 1 & Toprak Koruma (3. Derece) + Su Üretimi (2. Derece) + Rekreasyon \\
3 & 2 & 1 & 0 & Toprak Koruma (3. Derece) + Su Üretimi (2. Derece) + Estetik \\
3 & 1 & 0 & 0 & Toprak Koruma (3. Derece) + Su Üretimi (1. Derece) \\
3 & 2 & 0 & 0 & [Toprak Koruma (3. Derece) + Su Üretimi (2. Derece)] Üretim \\
\hline
\end{tabular}

Veri tabanına Toprak Koruma (TK), Su Koruma (SK), Estetik (E) ve Rekreasyon (R) fonksiyonları için girilen matematiksel değerlerin hangi anlamları ifade ettiği aşağıda açıklanmıştır.

* Toprak Koruma $(1,2,3)=(1) ; 1$.derece toprak korumay1, (2); 2.derece toprak korumay1, (3); 3.derece toprak korumayı ifade etmektedir.

* Su Üretimi $(1,2)=(1) ; 1$. derece su üretimi, (2) ise 2. derece su üretimini ifade etmektedir.

* Estetik $(1,0)=(1)$; Estetik fonksiyon görecek alanları, (0) ise estetik fonksiyona uygun olmayan alanları ifade etmektedir.

* Rekreasyon $(1,0)=(1)$; Rekreasyon fonksiyonu görecek alanları, (0) ise rekreasyon fonksiyonuna uygun olmayan alanları ifade etmektedir.

Bölme ya da bölmeciklerde ortaya çıkan kombinasyonlara göre fonksiyonların önceliklerine karar verilirken, fonksiyonları belirlemede kullanılan ölçüt ve göstergeler ile plan ünitesine ilişkin tüm verilerin yanında akademisyenler, plan denetim baş mühendisleri ve işletmedeki mühendislerin görüşleri dikkate alınacak şekilde katılımcı bir yaklaşım izlenmiştir. Plan ünitesine ilişkin fonksiyon kombinasyonlarından yararlanarak bölme ya da bölmeciklerdeki fonksiyon önceliklerinin nasıl belirlendiği aşağıdaki örneklerle açılanmıştır.

* Bölme veya bölmeciğe tek bir fonksiyon isabet etmişse o fonksiyon ana fonksiyon olarak kabul edilmiştir. Örneğin, (1--0--0--0) kombinasyonuna 1. derecede toprak koruma, (2--0--0--0) kombinasyonuna 2.derecede toprak koruma, (3--0--0--0) kombinasyonuna 3.derecede toprak koruma, (0--1--0--0) kombinasyonuna 1.derece su üretimi, (0--2--0--0) 2.derece su üretimi fonksiyonu atanmıştır.

* Bölme veya bölmeciğe birden fazla fonksiyon isabet etmişse o kombinasyon içerisinde değerlendirme yapılmıştır. Örneğin; (1--2--0--0) kombinasyonu 1. derecede toprak koruma fonksiyonu ve 2. derece su üretim fonksiyonuna ayrılması gereken bir alan/bölmeciktir. Toprak koruma fonksiyonun 1. derecede olduğu alanlarda ana fonksiyon toprak koruma, ikinci fonksiyon olarak da su üretim fonksiyonu dikkate alınmıştır.

* (2--1--1--0) kombinasyonu 2. derecede toprak koruma fonksiyonu, 1. derece su koruma fonksiyonu ve 1. derece estetik fonksiyon görecek alanlardan oluşmaktadır. Bu durumda estetik fonksiyonu ana fonksiyon olarak değerlendirilmiştir. Yan fonksiyonlar da öncelik sırasına göre su üretimi ve toprak koruma fonksiyonu olarak atanmıştır.

* (2--1--0--0) kombinasyonu 2. derecede toprak koruma fonksiyonu ve 1. derecede su üretim fonksiyonu görecek alanlardan oluşmaktadır. Bu durumda ana fonksiyon su üretimine verilmiştir. Yan fonksiyon ise toprak koruma fonksiyonu olarak belirlenmiştir.

* (3--2--0--1) kombinasyonu 3. derecede toprak koruma 2. derece su üretim fonksiyonu ve rekreasyon fonksiyonuna sahip alanlardan oluşmaktadır. $\mathrm{Bu}$ durumda 1. derecede rekreasyon fonksiyonu ana 
fonksiyon olarak değerlendirilmiştir. 2. derece yan fonksiyon su üretimi ve 3. derece yan fonksiyon toprak korumada fonksiyonu olarak değerlendirilmiştir.

* (3--2--0--0) kombinasyonu 3. derecede toprak koruma fonksiyonu ve 2. derecede su koruma fonksiyonu görecek alanlardan oluşmaktadır. Bu alanlarda erozyon riskinin daha az ve su üretiminin 2. derecede olmasından dolayı iç piyasanın yuvarlak odun üretimine olan talebinin karşılanması için odun üretim fonksiyonu olarak ayrılması uygun görülmüştür.

\section{Bulgular ve Tartışma}

Çalışma alanında orman fonksiyon haritası düzenlenirken her bir fonksiyon diğerinden bağımsız olarak değerlendirilmiş ve teknik veriler dikkate alınarak haritalandırılmıştır.

\subsection{Toprak Koruma Fonksiyonu}

Toprak koruma fonksiyon haritası oluşturulurken eğim (Şekil 2), anakaya (Şekil 3) ve meşcere yapısı haritaları (Şekil 4) birbirinden bağımsız olarak oluşturularak her üç haritanın üst üste çakıştırılması sonucunda nihai toprak koruma fonksiyonu erozyon risk grupları haritası olarak oluşturulmuştur (Şekil 5).

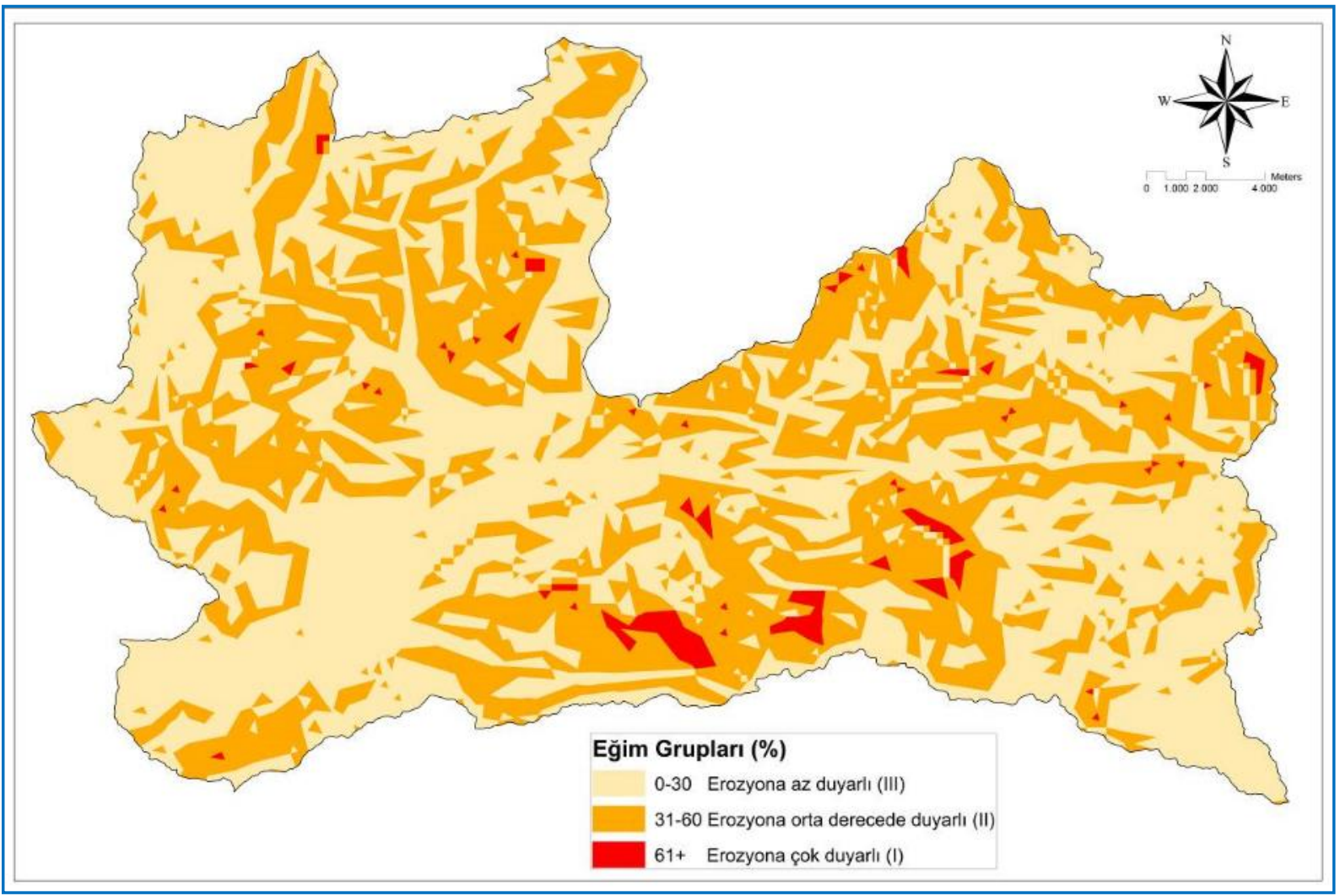

Şekil 2. Erozyon riskine göre eğim grupları haritası. 


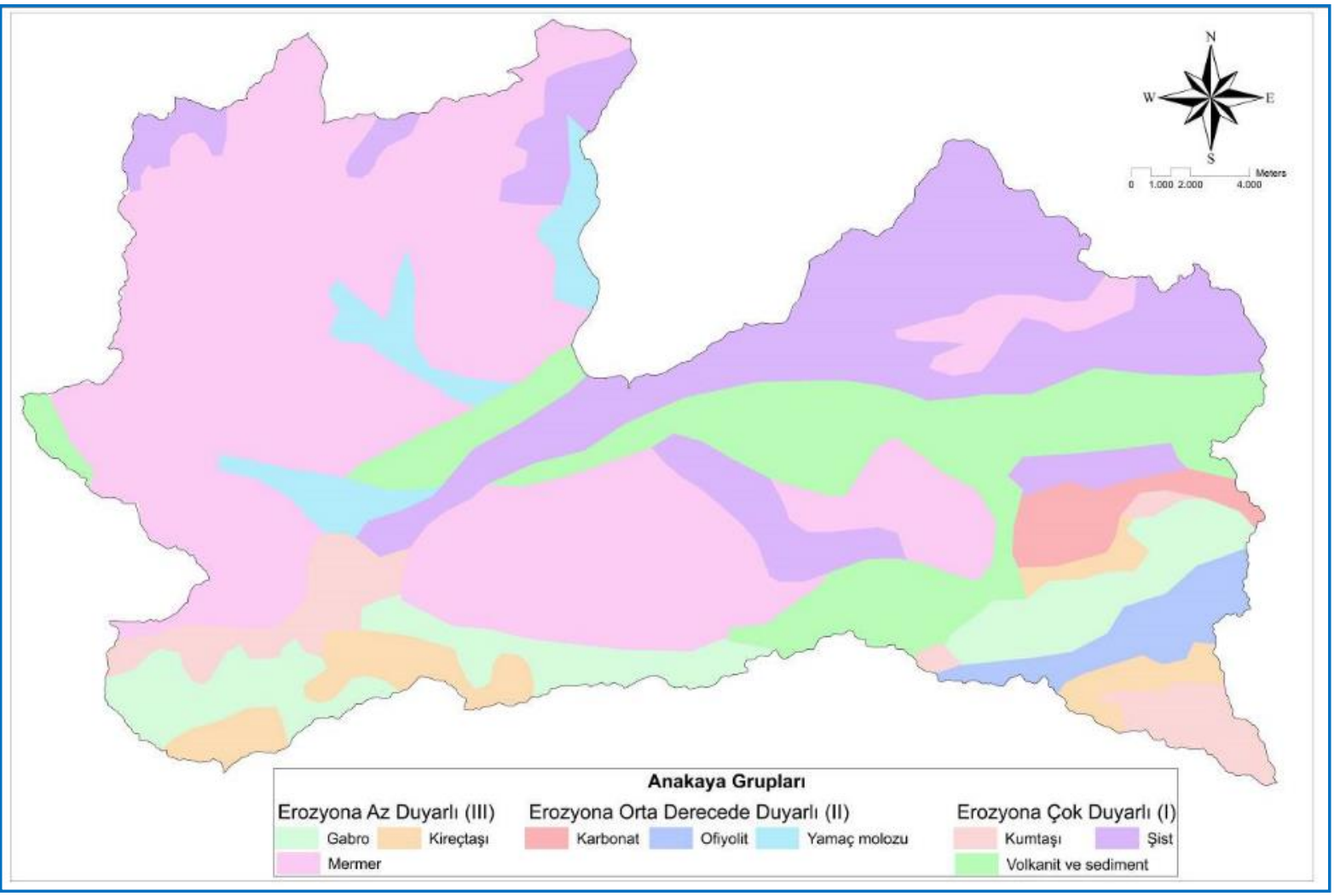

Şekil 3. Anakaya grupları haritası.

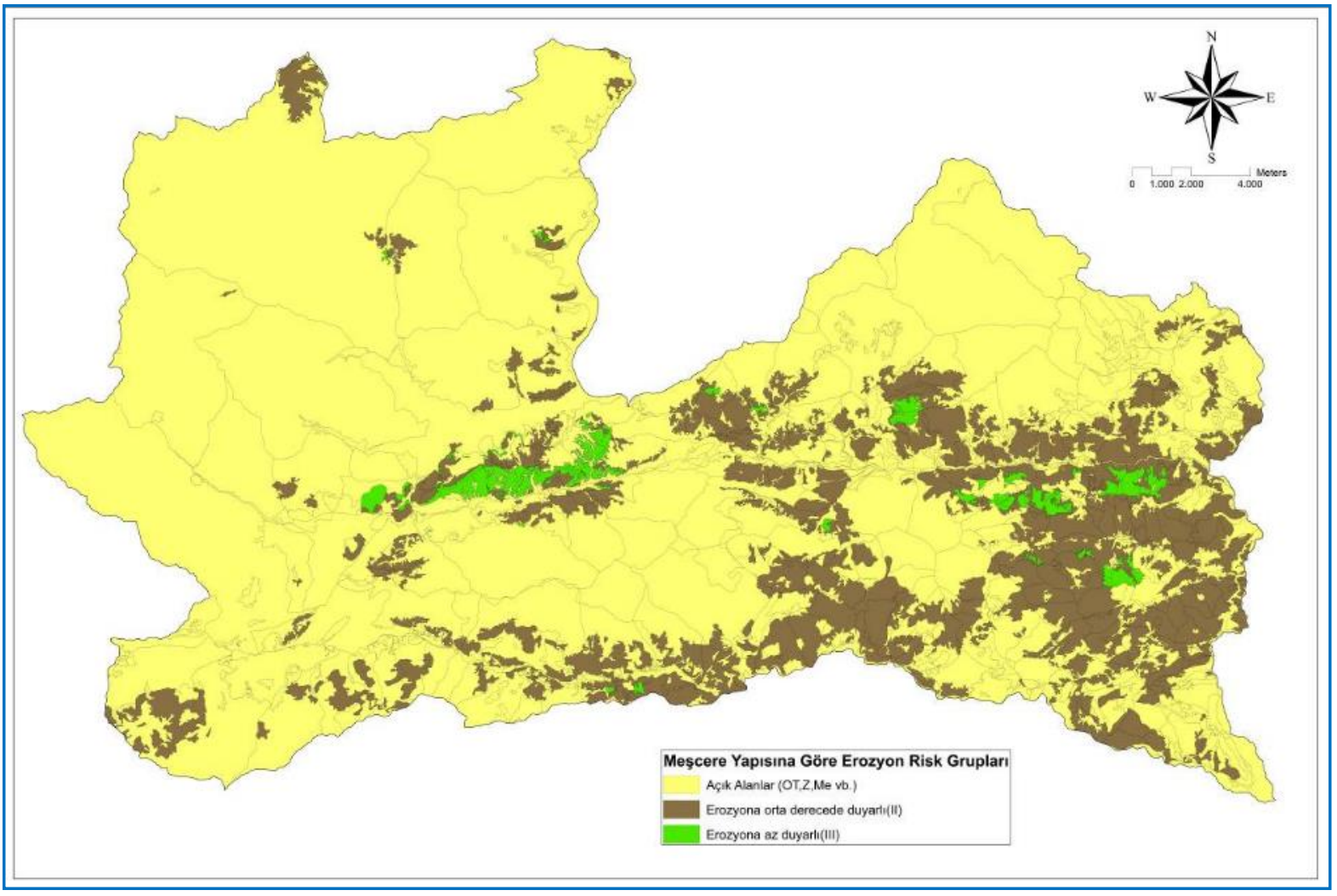

Şekil 4. Erozyon riskinin meşcere yapısına (kapalılık ile kök sistemine) göre değişimi. 


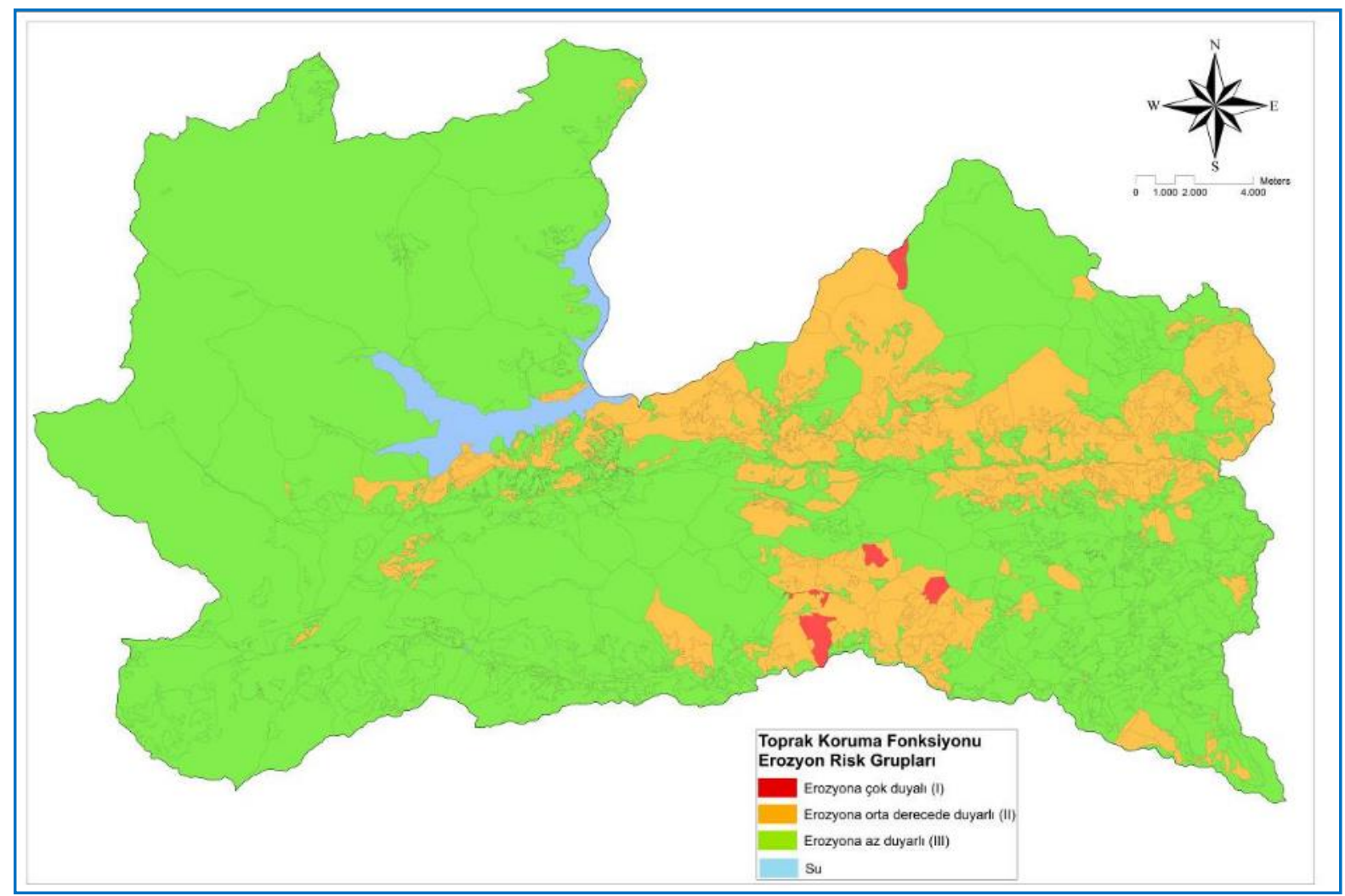

Şekil 5. Nihai toprak koruma fonksiyon haritası.

Birbirlerinden bağımsız olarak eğim, anakaya, meşcere yapısına (kapalılık ve kök sistemine) göre oluşturulan haritaların üst üste çakıştırılması sonucunda nihai toprak koruma fonksiyon haritası oluşturulmuştur (Şekil 5). Buna göre alanın \%0,43’ü erozyona çok duyarlı, \%21,71'i erozyona orta derecede duyarlı ve \%77,86's1 ise erozyona az duyarlı olarak bulunmuştur (Tablo 6).

Tablo 6. Toprak koruma fonksiyonunun erozyon risk gruplarına göre alan dağılımı.

\begin{tabular}{lll}
\hline Erozyon Risk Grupları & Alan (ha) & \% \\
\hline (I) Erozyona çok duyarlı & 284,34 & 0,43 \\
(II) Erozyona orta derecede duyarlı & $14.364,02$ & 21,71 \\
(III) Erozyona az duyarlı & $51.509,64$ & 77,86 \\
Toplam & $66.157,0$ & 100 \\
\hline
\end{tabular}

\subsection{Su Üretim Fonksiyonu}

Su üretim fonksiyonuna ayrılacak alanlar belirlenirken Çat baraj gölüne su taşıyan akarsuların su toplama havzaları dikkate alınarak sırtlardan geçecek şekilde yapılmıştır. Çat baraj gölü havzasının bulunduğu kısım 1.derecede su üretim fonksiyonuna ayrılırken, plan ünitesinin kalan kısmı da 2. derecede su üretim fonksiyonuna ayrılmıştır (Şekil 6). Yazları çok sıcak ve kurak bir iklim yapısına sahip olması nedeniyle plan ünitesinin tamamı su üretim fonksiyonunu ihtiva etmektedir. 


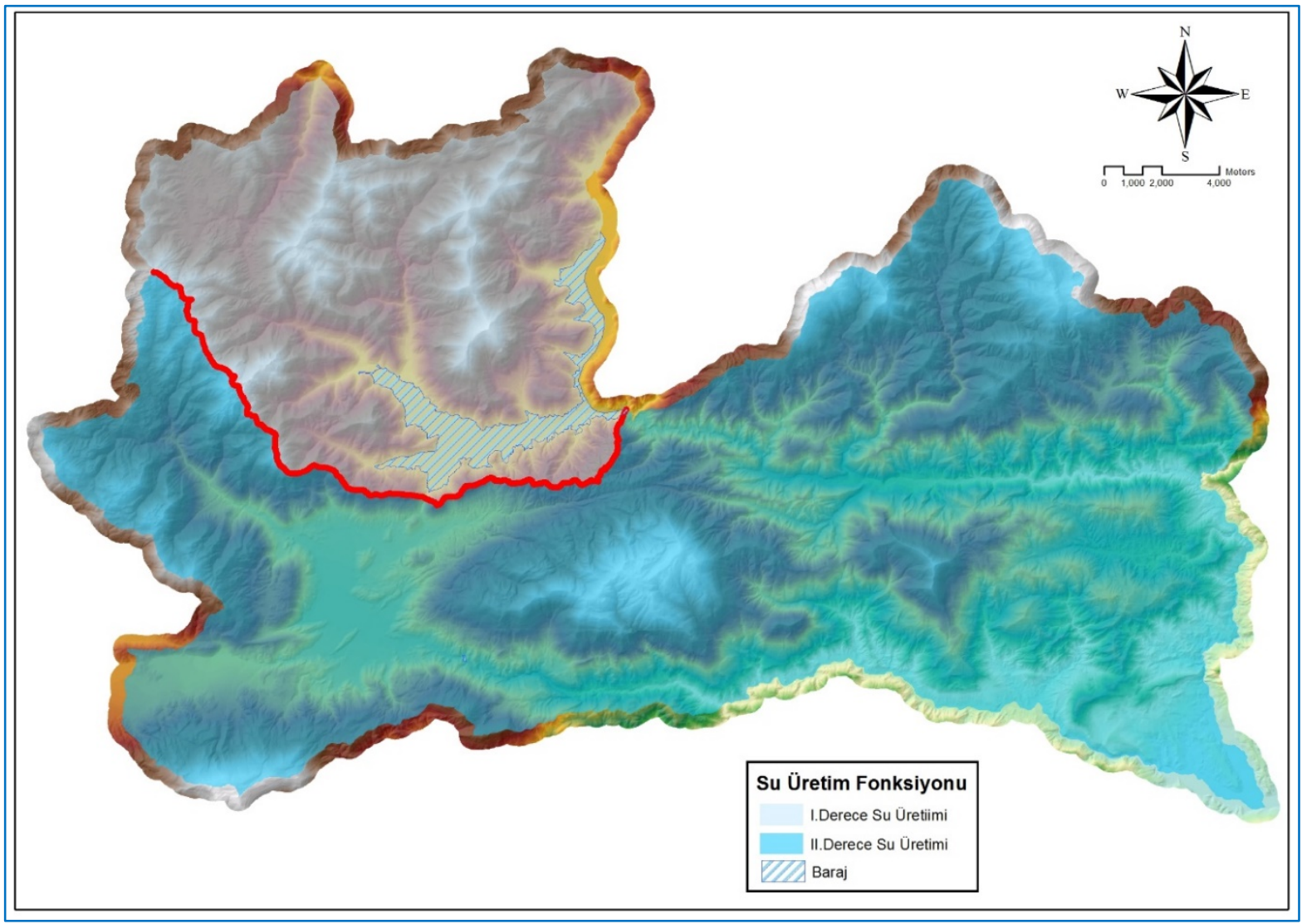

Şekil 6. Su üretim fonksiyonuna ayrılan alanlar.

\subsection{Estetik Fonksiyon}

Çelikhan ilçe merkezi ile Çat baraj gölü kıyıları ve ana karayolu etrafında dikimle oluşturulan saf karaçam meşcereleri estetik fonksiyon açısından uygundur. Bu alanlar halk tarafından yoğun olarak kullanılmaktadır. Plan ünitesi içerinde estetik fonksiyona ayrılan alan 303,78 ha'dır (Şekil 7).

\subsection{Rekreasyon Fonksiyonu}

Rekreasyon fonksiyonuna ayrılan alanlar (Şekil 7) yöre halkı tarafindan fiili olarak bu amaçla kullanılmaktadır. Bozuk meșe meșcere tipine sahip alan 25,61 ha'lık bir alandan oluşmakta olup içerisinden ana karayolu geçmektedir. 


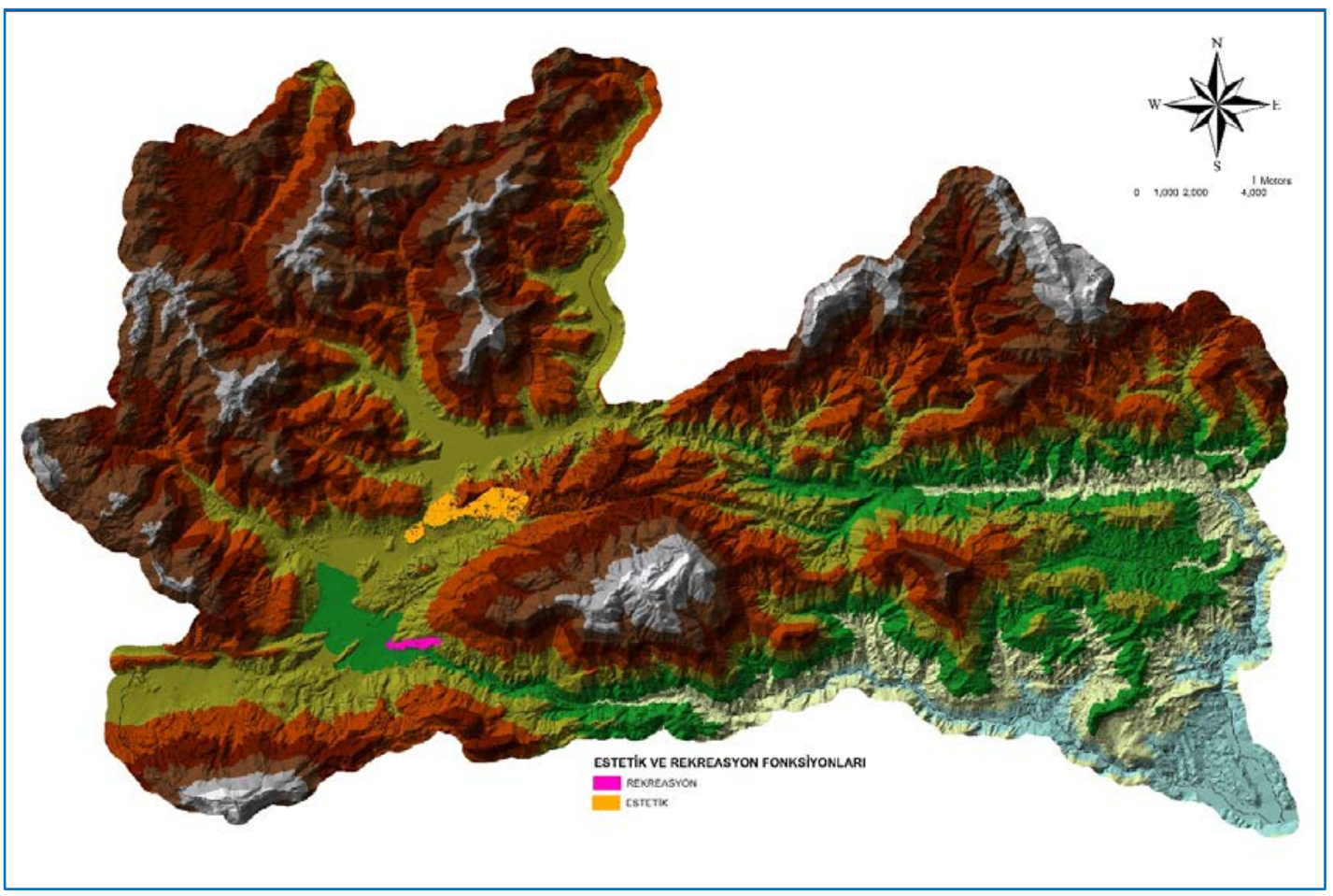

Şekil 7. Estetik ve rekreasyon fonksiyona ayrılan alanlar.

\subsection{Nihai Fonksiyon Haritası}

Birbirinden bağımsız şekilde toprak koruma, su koruma, estetik ve rekreasyon fonksiyonları için oluşturulan haritalar üst üste çakıştırılarak tek bir harita üzerinde birleştirilmiştir. Her bir fonksiyon ayrı renk ve tarama ile gösterilmiştir (Şekil 8).

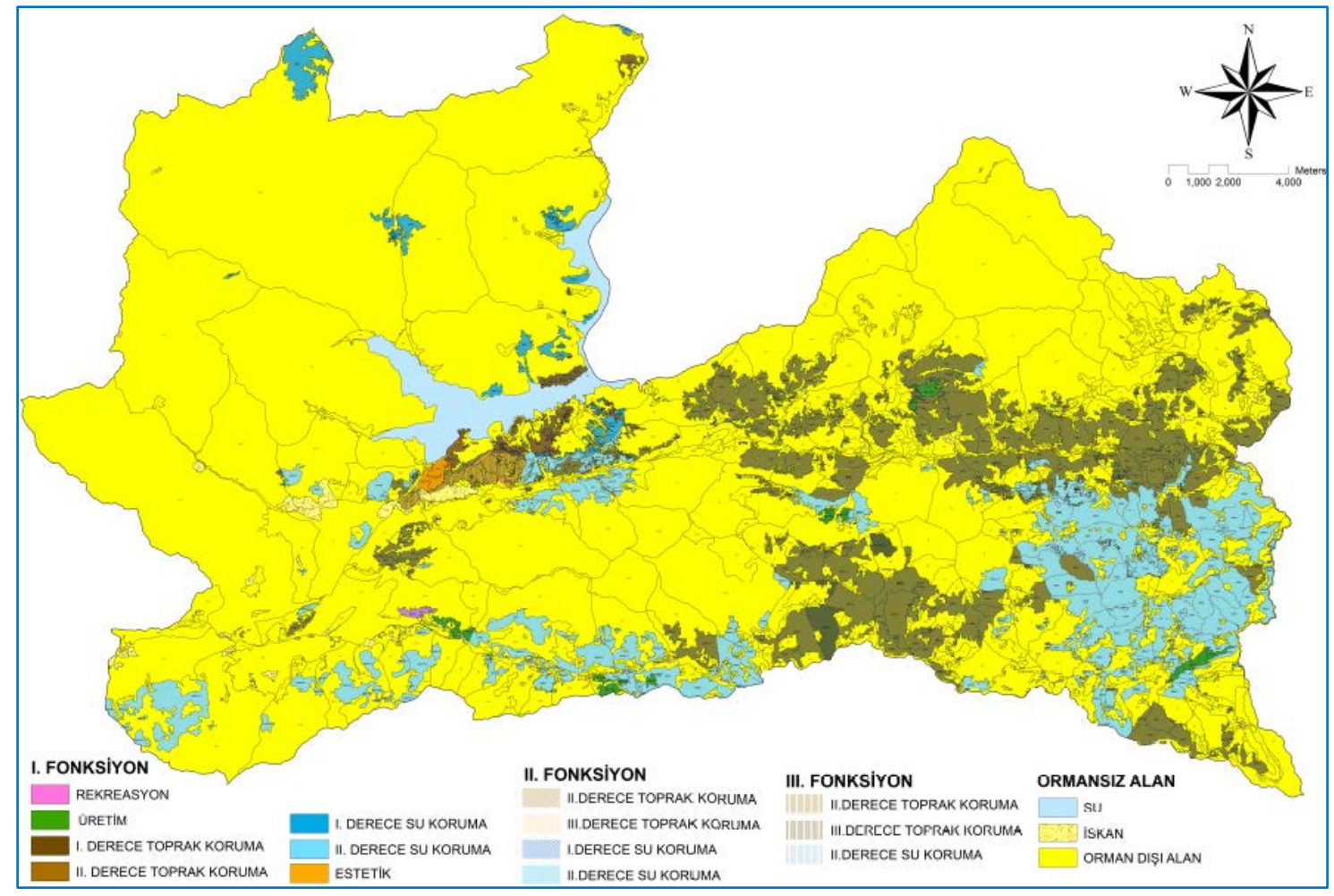

Şekil 8. Plan ünitesinin nihai orman fonksiyon haritası. 
Orman fonksiyon haritasına göre; I. Fonksiyonların dağılımında toprak koruma \%9,61, su koruma \%9,27, üretim $\% 0,31$, rekreasyon \%0,04, estetik \%0,46 ve ormansız alan \%61,54'dir (Tablo 7). Ormanlık alan toplamının (13.291,2 ha) \%2,29 estetik, \%0,19 rekreasyon ve \%1,55 üretim ormanından oluşmaktadır.

Tablo 7. Orman fonksiyon önceliklerinin alana dağılımı.

\begin{tabular}{lllll}
\hline \multirow{2}{*}{ Fonksiyonlar } & I. Fonksiyon & & II. Fonk. & III. Fonk. \\
\cline { 2 - 5 } & alan (ha) & \% & alan (ha) & alan (ha) \\
\hline Toprak Koruma & $6.356,39$ & 9,61 & $6.226,88$ & 419,23 \\
Su Koruma & $6.135,82$ & 9,27 & $6.787,36$ & 104,94 \\
Estetik & 303,78 & 0,46 & & \\
Rekreasyon & 25,61 & 0,04 & & 129,60 \\
Üretim & 206,51 & 0,31 & 13,88 & \\
Ormansiz Alan & $40.711,37$ & 61,54 & & \\
Su (Baraj Alani) & $12.417,52$ & 18,77 & & 653,77 \\
Toplam & $66.157,00$ & 100 & $13.028,12$ & \\
\hline
\end{tabular}

Plan ünitesi içerisindeki konumsal orman fonksiyonları ile bireysel ve kurumsal talebe konu olan estetik ve rekreasyon fonksiyonları ayrıldıktan sonra erozyon riskinin az ve eğimin düşük olduğu alanlar üretim fonksiyonuna ayrılmıştır. Bu alanlar toplam alanın \%0,31'ini oluşturmaktadır (Tablo 7).

\section{Sonuç ve Öneriler}

Ormanların topluma sunmuş olduğu birçok faydaları olmasına rağmen, orman amenajman planlarının yapımında yıllarca odun üretiminin planlanmasına ve buna dayalı yöntemlerin geliştirilmesine çalışılmıştır. Bütün dünyada olduğu gibi ülkemizde de hızlı bir şekilde artan nüfusun doğal kaynaklardan beklediği faydalar da artmakta ve çeşitlenmektedir. Kentsel alanlara olan yoğun talep nedeniyle ormanların ekolojik ve sosyo kültürel fonksiyonları ön plana çıkmıştır. İşletmeciler de bu fonksiyonların sürdürülebilir olarak işletilmesi amacıyla toplumun taleplerine cevap verecek şekilde ormanların planlanması gerektiğini öngörmüşlerdir.

Asan ve Özdemir (2002) tarafından yapılan çalışmada ve halen yürürlükte bulunan orman amenajman yönetmeliğinde toprak koruma fonksiyonuna ayrılacak alanlar belirlenirken sadece eğim kriteri baz alınmaktadır. $\mathrm{Bu}$ çalışmada eğim, anakaya grupları ile meşcere yapısı, kök sistemi ve kapalılık gibi veriler bir arada kullanılarak toprak koruma fonksiyonuna ayrılması gereken alanlar ortaya koyulmuştur. Böylece toprak koruma fonksiyonu için eğim parametresine ilaveten başka kriterler ortaya konularak erozyona hassas alanlar risk gruplarına göre belirlenmiştir.

Plan ünitesi için teknik verilere dayalı olarak belirlenen taslak fonksiyon haritasından faydalanılarak nihai fonksiyon haritasının oluşturulması aşamasında, fonksiyon kombinasyonlarından ana ve yan fonksiyonlar tespit edilirken yani işletme amaçları saptanırken süreci tam işletilmiş katılımcı yaklaşım kullanılmıştır.

Orman fonksiyon haritaları amenajman heyetleri tarafından yapılabileceği gibi bağımsız gruplar tarafından ülke genelinde belirlenerek amenajman heyetlerine altlık olarak verilebilir. Bu potansiyel fonksiyonlar belirlenirken özellikle işletme müdürlüğünün tamamında ya da havza bazında yapılması daha gerçekçi olacaktır. Örneğin, su üretim fonksiyonuna ayrılacak alanlar belirlenirken mutlaka havzanın tamamının bu fonksiyonu içereceği gerçeği göz önünde bulundurulmalıdır. Buradan hareketle plan ünitelerinin sınırlarının havza sınırlarına dayandırılması gerektiği çıkarılabilir. Ormanlardan beklenen ihtiyaç ve talepler planların hazırlanması aşamasında tüm paydaşların katılımı ile gerçekleştirilerek olursa bu gibi eksiklikler giderilmiş olacaktır.

\section{Teşekkür}

Katkılarından dolayı Orman Genel Müdürlüğü ve Orman İdaresi ve Planlama Dairesi Başkanlığına, akademisyenlere ve işletme mühendislerine çok teşekkür ederim. 


\section{Kaynaklar}

1. Anonim (1986). MTA Genel Müdürlüğü, 1/100 000 Ölçekli Türkiye Jeoloji Haritaları, Malatya - İ27 Paftas1, Ankara.

2. Anonim (2002). Orman Fonksiyonları, Fonksiyonel Alanların Belirlenmesinde Kullanılacak Kriterler ve Uygulanacak Silvikültürel İlkeler, TC Orman Bakanlığı OGM Silvikültür Dairesi Başkanlığı, Ankara, Tamim No: 6273, Tasnif No: 1961, 34.

3. Asan, Ü. (1990). Orman Kaynaklarının Çok Amaçlı Kullanımı ve Fonksiyonel Planlama. İ.Ü. Orman Fakültesi Dergisi, Seri: B, Cilt: 40, Sayı: 3, Sayfa: 67-84, İstanbul.

4. Asan, Ü. (1992). Orman Amenajmanında Fonksiyonel Planlama ve Türkiye'deki Uygulamalar. Ormancılı̆̆ımızda Orman Amenajmanının Dünü,Bugünü ve Geleceğine İlişkin Genel Görüşme, Bildiriler Kitabl, Sayfa: 181-196, Ankara.

5. Asan, Ü. (1995). Orman Kaynaklarının Rasyonel Kullanımı ve Ülkemizdeki Durum. İ.Ü. Orman Fakültesi Dergisi, Seri: B, Cilt: 45, Sayı: 3-4, Sayfa: 15-27, İstanbul.

6. Asan, Ü. (1999). Orman Fonksiyonlarının Haritalanması ve İşletme Sınıfı Ayrımı İ.Ü. Orman Fakültesi Dergisi, Seri: B, Cilt: 49, Say1:1-2-3-4, Sayfa: 19-29, İstanbul.

7. Asan, Ü., Ercan, M. (2002). Orman Amenajmanında Yeni Açılımlar ve Uygulamalar (Kerpe Örneği). Orman Amenajmanı'nda Kavramsal Açılımlar ve Yeni Hedefler Sempozyumu - Prof. Dr. Bekir Sitkı Evcimen'in Anısina (18-19 Nisan 2002, İ.Ü. Orman Fakültesi), Bildiriler Kitabl, Sayfa: 8-22, İstanbul.

8. Asan, Ü., Özdemir, İ. (2002). İstanbul Korularında Konumsal Fonksiyonların Belirlenmesi ve Haritalanması. Orman Amenajmanı'nda Kavramsal Açılımlar ve Yeni Hedefler Sempozyumu - Prof. Dr. Bekir Sitkı Evcimen'in Anısına (18-19 Nisan 2002, İ.Ü. Orman Fakültesi), Bildiriler Kitabl, Sayfa: 67-76, İstanbul.

9. Asan, Ü., Yeşil, A. (1993). Orman Amenajmanında Model Plan Düşünceleri ve Son Uygulama Örnekleri. I. Ü. Orman Fakültesi Dergisi, Seri: B, Cilt: 43, Say1: 1-2, Sayfa: 31-44, İstanbul.

10. Asan, Ü., Yeşil, A., Destan, S. (1997). The Role of Functional Planning in the Rational Usage of Forest Resources. Proceedings of the XI. World Forestry Congress (13-22 October 1997), 6 pages, Antalya, Turkey.

11. Asan, Ü., Yeşil, A., Destan, S., Özdemir, İ., Zengin, H. (2005). Sürdürülebilir Orman İşletmeciliğinin Gerçekleştirilmesinde Fonksiyonel Planların Yeri ve Önemi, Türk Ormancıllğında, Uluslararası Süreçte Acil Eyleme Dönüştürülmesi Gereken Konular, Mevzuat ve Yapılanmaya Yansımaları Sempozyumu, Orman Mühendisleri Odas1, 22-24 Aralık 2005, Antalya.

12. Balcı, A.N. (1996). Toprak Koruması. İ.Ü. Orman Fakültesi Yayını. İ.Ü. Yayın No: 3947, Orman Fakültesi Yayın No: 439. ISBN: 975-404-423-6.

13. Balcı, A.N., Öztan, Y. (1987). Sel Kontrolü. K.T.Ü., Orman Fakültesi Yayın No: 12. Trabzon.

14. Balcı, N. (1978). Kurak ve Nemli İklim Koşulları Altında Gelişmiş Bazı Orman Topraklarının Erodibilite Karakteristikleri. İ.Ü. Yayın No: 2402, Orman Fakültesi Yayın No: 248

15. Başkent, E.Z., Mumcu Küçüker, D. (2010). Incorporating water production and carbon sequestration into forest management planning: a case study in Yalnızçam planning unit. Forest Systems: 19, 98-111.

16. Baud-Bovy, M., Lawson, F. (1998). Tourism and Recreation Handbook of Planning and Design, Oxford Architectural press, 287s.

17. Bettinger, P., Siry, J., Cieszewski, C., Merry K., L., Zengin, H., Yeşil, A. (2013). Forest management 1ssues of southern united states and comparisons with Turkey. Turkish Journal of Agriculture and Forestry 37:83-96

18. Bozali, N. (2013). Koruma ve Hizmet Amaçlı İşletilen Ormanların Optimal Kuruluşunun Belirlenmesi: Odayeri Planlama Ünitesi Örneği. Doktora Tezi (yayımlanmamış), İ.Ü. Fen Bilimleri Enstitüsü, İstanbul.

19. Bozali, N. (2020). Assessment of the soil protection function of forest ecosystems using GIS-based MultiCriteria Decision Analysis: A case study in Adiyaman, Turkey. Global Ecology and Conservation (Under Review)

20. Butler, R., Hall, C. M., Jenkins, J. (1998). Tourism and Recreation in Rural Areas, John Willey \& Sons, 274s, New York.

21. Daşdemir, İ., Güngör, E. (2010). Çok kriterli ve katılımcı yaklaşımla orman kaynaklarının işlevsel önceliklerinin belirlenmesi: Ulus devlet orman işletmesi örneği. Bartın Orman Fakültesi Dergisi, Cilt: 12, Say1: 17, 11-25.

22. Eler, Ü. (2001). Orman Amenajmanı, Süleyman Demirel Üniversitesi Orman Fakültesi. SDÜ Basımevi. No:17. ISSN:975-7929-36-0. 199 s. Isparta.

23. Eraslan, İ. (1982). Orman Amenajmanı. Değiştirme ve İlavelerle Yeniden İşlenmiş Dördüncü baskı. İ.Ü. Orman Fakültesi Yayını. İ.Ü. Yayın No: 3010. Orman Fakültesi Yayın No: 318 
24. Geray, A. U., Şafak, İ., Yılmaz, E., Kiracıoğlu, Ö., Başar, H. (2007). İzmir İlinde Orman Kaynaklarına İlişkin İşlev Önceliklerinin Belirlenmesi. Eğe Ormancılık Araştırma Müdürlüğü Yayın No: 46, Teknik Bülten No:35, 137 s., İzmir.

25. Ji, J., Kokutse, N., Genet, M., Fourcaud, T., Zhang, Z. (2012). Effect of spatial variation of tree root characteristics on slope stability: A case study on Black Locust (Robinia pseudoacacia) and Arborvitae (Platycladus orientalis) stands on the Loess Plateau, China. Catena, 92, 139-154.

26. Kahveci, G. (1999). Orman Fonksiyon Haritaları, Orman Mühendisliği Dergisi, Sayı 4, s. 8.

27. Karahalil, U. (2003). Toprak Koruma ve Odun Üretimi Fonksiyonlarının Doğrusal Programlama ile Modellenmesi. Yüksek Lisans Tezi (yayımlanmamış), K.T.Ü. Fen Bilimleri Enstitüsü.

28. Keleş, S. (2003). Ormanların Su ve Odun Üretimi Fonksiyonlarının Doğrusal Programlama Tekniği ile Optimizasyonu (Karanlıkdere Planlama Birimi Örneği). Yüksek Lisans Tezi, (yayımlanmamış), K.T.Ü. Fen Bilimleri Enstitüsü.

29. Keleş, S., Kadığulları, A.İ., Başkent, E.Z. (2005). Tamsayılı programlama tekniği ile ormanların çok amaçlı planlanması, Erciyes Üniversitesi Fen Bilimleri Enstitüsü Dergisi 21(1-2), S. 223-234.

30. Köse, S. (1986). Orman İşletmelerinin Planlanmasında Yöneylem Araştırma Yöntemlerinden Yararlanma Olanakları. Doktora Tezi (yayımlanmamış), KTÜ Fen Bilimleri Enstitüsü, 126 s., Trabzon.

31. Köse, S., Mısır, M., Yolasığmaz, H.A. (1998). Coğrafi Bilgi Sistemleri ile Orman Fonksiyon Haritalarının Hazırlanması. Cumhuriyetin 75. Yılında Ormancılı̆̆ımız Sempozyumu, Bildiri Kitabı, İÜ Yayın No: 4187,Orman Fakültesi Yayın No: 458, s. 267-275., İstanbul.

32. Kucuker, D., Başkent, E.Z. (2017). Impact of forest management intensity on mushroom occurrence and yield with a simulation-based decision support system. Forest Ecology And Management , 389, 240-248.

33. Mısır, M. (2001). Çok Amaçlı Orman Amenajman Planlarının Coğrafi Bilgi Sistemlerine Dayalı Olarak Amaç Programlama Yöntemiyle Düzenlenmesi (Ormanüstü Planlama Birimi Örneği İle). Doktora Tezi (yayınlanmamış), KTÜ Fen Bilimleri Enstitüsü, 155 s., Trabzon.

34. Mısır, M. (2005). Çok amaçlı planlamanın kavramsal çatısı ve örnek uygulama, Kafkas Üniversitesi Artvin Orman Fakültesi Dergisi, Cilt. 6, s 17-27.

35. Mısır, M., Başkent, E.Z. (2002). Çok Amaçlı Orman Amenajman Planlarının Amaç Programlama Yöntemi ile Düzenlenmesi. Orman Amenajmanı'nda Kavramsal Açılımlar ve Yeni Hedefler Sempozyumu, Bildiriler Kitabı, İÜ Orman Fakültesi, İstanbul.

36. Özdemir, İ., Asan, Ü., Özkan, U.Y. (2005). Konumsal orman fonksiyonlarının haritalanmasının önemi ve sayısal arazi modelinden yararlanma olanakları, SDÜ Fen Bilimleri Enstitüsü Dergisi, 9-1, s 1-7.

37. Özhan, S. (2004). Havza Amenajmanı. İ.Ü. Orman Fakültesi Yayını. İ.Ü. Yayın No: 4510. Orman Fakltesi Yayın No: 481

38. Şafak, İ. (2009). Orman mühendisleri açısından Ege Bölgesi’ndeki önemli orman işlevleri. Bartın Orman Fakültesi Dergisi, 1. Ulusal Batı Karadeniz Ormancılık Kongresi Bildiriler Kitabı 2009, Özel Sayı, ISSN:1302- 0943, Cilt:II, s:626-632.

39. Yılmaz, E. Keleş, H., Koçak, Z. (2010). Mersin İlinde Orman Kaynaklarına İlişkin İşlev Önceliklerinin Belirlenmesi. Doğu Akdeniz Ormancılık Araștırma Enstitüsü, Teknik Bülten no:35, 260s

40. Yolası̆̆maz, H.A. (1998). Coğrafi Bilgi Sistemleri İle Orman Fonksiyon Haritalarının Hazırlanması. Yüksek Lisans Tezi (yayımlanmamış), KTÜ Fen Bilimleri Enstitüsü, 97 s., Trabzon.

41. Zengin, H. (2009). Orman Kaynaklarından Fonksiyonel Yaklaşım ile Çok Amaçlı Faydalanmanın Optimizasyonu, Doktora Tezi (yayımlanmamış), İstanbul Üniversitesi, Fen Bilimleri Enstitüsü, İstanbul.

42. Zengin, H., Yeşil, A., Asan, Ü., Bettinger, P., Cieszewski, C., Siry, J. (2013). Evolution of Modern Forest Management Planning in the Republic of Turkey. Journal of Forestry: 111-4 